\title{
Effects of chitosan on healing and strength of colonic anastomosis in rats ${ }^{1}$
}

\author{
Efeitos de quitosana na cicatrização e resistência de anastomose colônica em ratos
}

\begin{abstract}
Bulent Citgez ${ }^{\mathrm{I}}$, Ahmet Nurettin Cengiz ${ }^{\mathrm{II}}$, Ismail Akgun ${ }^{\mathrm{III}}$, Mehmet Uludag ${ }^{\mathrm{IV}}$, Gurkan Yetkin ${ }^{\mathrm{IV}}$, Neslihan Bahat ${ }^{\mathrm{V}}$, Omer Ozcan ${ }^{\mathrm{VI}}$, Nedim Polat ${ }^{\mathrm{VII}}$, Adem Akcakaya ${ }^{\mathrm{VIII}}$, Oguzhan Karatepe ${ }^{\mathrm{IX}}$

${ }^{\mathrm{I}} \mathrm{MD}$, Sisli Etfal Training and Research Hospital, General Surgery $2^{\text {nd }}$ Department, Istanbul, Turkey. Main author, designed the research and analyzed the data, manuscript writing.

IIMD, Sisli Etfal Training and Research Hospital, General Surgery $2^{\text {nd }}$ Department, Istanbul, Turkey. Surgical procedures, collection of data.

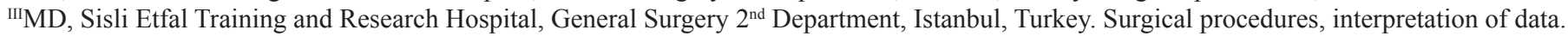

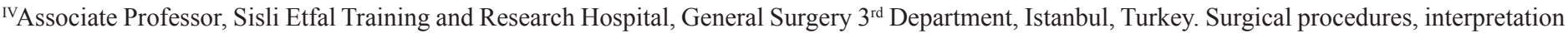
of data, critical revision.

${ }^{v}$ MD, Sisli Etfal Training and Research Hospital, Department of Obstetrics and Gynecology, Istanbul, Turkey. Surgical procedures, analysis of data.

VIMD, GATA Haydarpasa Training Hospital, Istanbul, Turkey. Surgical procedures.

${ }^{\mathrm{VII}} \mathrm{MD}$, Sisli Etfal Training and Research Hospital, Pathology Department, Istanbul, Turkey. Histological analysis.

${ }^{\text {VIII }}$ Associate Professor, Sisli Etfal Training and Research Hospital General Surgery $2^{\text {nd }}$ Department, Istanbul, Turkey. Analysis of data, critical revision.

${ }^{\mathrm{Ix}}$ Associate Proffessor, Bezmialem Vakif University, Surgery, İstanbul,Turkey. Analysis of data, manuscript revision.
\end{abstract}

\section{ABSTRACT}

PURPOSE: To investigate whether chitosan application over colonic anastomosis line, provide reinforcement, and subsequently improve anastomotic healing.

METHODS: Forty eight Wistar albino female rats were used and were randomly divided into four groups, 12 rats in each: The control groups (1 and 3) received no further treatment. The experimental groups (2 and 4) received chitosan application over the colonic anastomosis. After sacrifying rats at the end of the experiment (either on day three or on day seven, depending on the group), colonic bursting pressure, a hihydroxyproline level and histopathologic characteristics of the perianastomotic tissue were examined.

RESULTS: At three days, chitosan and control groups had similar values for histopathologically. On day seven, chitosan group had significantly higher mean score of collagenization $(\mathrm{p}=0.007)$ and a significantly higher bursting pressure $(\mathrm{p}=0.038)$.

CONCLUSION: Our study emphasizes the positive effect of chitosan in the process of collagenation in colonic anastomosis healing.

Key words: Chitosan. Anastomosis, Surgical. Tensile Strength. Wound Healing. Rats.

\section{RESUMO}

OBJETIVO: Investigar se a aplicação de quitosana em anastomose colônica promove resistência à tração e consequentemente a melhora na cicatrização.

MÉTODOS: Foram utilizados 48 ratos Wistar fêmeas distribuídos em quatro grupos, 12 ratos em cada. Grupos controle (1 e 3 ) não receberam tratamento. Grupos experimento ( 2 e 4 ) receberam aplicação de quitosana na anastomose colônica. Após eutanásia após $3^{\circ}$ ou $7^{\circ}$ dias foram examinadas a tensão, o nível de hidroxiprolina e aspectos histopatológicos da anastomose.

RESULTADOS: Após três dias os grupos controle e quitosana não apresentaram alterações histopatológicas. No sétimo dia o grupo quitosana apresentou significante elevação do escore de colagenização $(p=0,007)$ e da tensão de ruptura $(p=0,038)$.

CONCLUSÃO: A quitosana apresentou bons resultados nos processos de colagenização e cicatrização de anastomose colônica.

Descritores: Quitosana. Anastomose Cirúrgica. Resistência à Tração. Cicatrização. Ratos. 


\section{Introduction}

Gastrointestinal anastomoses are among the most frequently performed procedures in general surgery units throughout the world. From a clinical viewpoint, anastomoses are an essential part of the surgical management for many benign or malignant conditions of the gastrointestinal system and considerable effort has been devoted by colorectal surgeons to prevent anastomosis-associated complications.

Anastomotic leak is the single most important determinant for mortality, morbidity, and the length of hospital stay $^{1,2}$ after anastomoses. Within the gastrointestinal system, the risk of anastomotic leak is highest in the large intestine. However, the risk is not uniformly distributed in this anatomical location: the more distal the anastomosis in the large intestine the greater the likelihood of anastomotic leak ${ }^{1,3}$. Relative scarcity of collateral circulation together with a very rich bacterial flora may help to explain the higher probability of leaks in this area ${ }^{4}$. Another factor associated with increased risk is the frequent occurrence of coexistent pathologies in most of the patients undergoing colon surgery ${ }^{5}$.

Chitosan is a linear copolymer of $\beta^{1,4}$ linked 2-acetamido-2-deoxy- 3 -D-glucopyranose and 2-amino-2-deoxyßD-glycopyranose. It is easily obtained by deacetylation of chitin, an abundant polysaccharide found in nature as a component of exoskeletons of crustaceans and insects. Chitosan has been reported to be a biocompatible, biodegradable and non-toxic substance with antifungal, hemostatic, antimicrobial, analgesic, and wound healing accelerating effects ${ }^{6,7}$. Several studies have shown the activity of chitosan in the healing process through enhanced infiltration of inflammatory cells in the area of injury. Furthermore, chitosan-mediated stimulation of macrophage and fibroblast activity during wound healing has resulted in a more pronounced formation of granulation tissue ${ }^{8,9}$. Other studies have provided evidence for accelerated wound healing with chitosan gel formulations ${ }^{10,11}$.

Fibroblasts produce the main constituents of the connective tissue, i.e. collagen, proteoglycans, and elastins, and play a role in wound healing. Collagen, the most abundant protein in human body, is responsible for the integrity and durability of tissues. Collagen content of the tissues, which is a surrogate marker for anastomotic healing, is estimated on the basis hydroxyproline $\operatorname{assay}^{6,12}$.

This experimental study aimed to investigate any potential favorable effects of chitosan application over colonic anastomoses on anastomosis strength and reactions taking place during healing process.

\section{Methods}

Forty eight Wistar albino female rats weighing between 200-250g were used for this study. The animals were fed with standard rat food and drinking water with 12-hour day and night periods at an ambient temperature of $25^{\circ} \mathrm{C}$. Rats were randomly divided into four groups, which were kept in separate cages. Rats that died during the follow-up were not included in the assessments and were replaced with another. The study protocol was approved by the ethics committee of the Experimental Medicine Research Institute, University of Istanbul (DETAE).

Four equally numbered groups were created as follows:

Group 1: Control (sham) group $(\mathrm{n}=12)$. Performed colonic anastomosis +3 day scarification;

Group 2: Treatment group $(\mathrm{n}=12)$. Performed colonic anastomosis + applied chitosan +3 day scarification;

Group 3: Control group $(\mathrm{n}=12)$. Performed colonic anastomosis +7 day scarification;

Group 4: Treatment group $(\mathrm{n}=12)$. Performed colonic anastomosis + applied chitosan +7 day scarification.

All rats were sacrificed at the end of the experiment to assess bursting pressure, hydroxyproline level and histopathologic characteristics of the perianastomotic tissue.

\section{Surgical procedures}

Surgical procedures were performed under strictly sterile conditions and all rats were fasted for 12 hours prior to the operation. After general anesthesia was administered with $10 \mathrm{mg}$ / $\mathrm{kg}$ of subcutaneous ketamine (Ketalar, Eczacıbaşı, Ist.), anterior abdominal wall was shaved and cleansed with povidon iodine and covered with sterile surgical drapes. A $3 \mathrm{~cm}$ midline incison was made to access the abdominal cavity. Left colon was exposed and a full-layer cut was made in a right angle to its longitudinal axis. Then, end-to-end colo-colic anastomosis was performed using 5/0 absorbable monofilamentous polydiaxanon (PDS; Johnson \& Johnson Professional Export Company Ethicon Ltd, Edinburgh, England) with inverting sutures. All anastomoses were performed by the same surgeon using seven to eight sutures for each anastomosis. The fascia and skin were closed with continuous sutures using 3/0 silk suture material. Postoperatively the animals were fed with standard rat food and drinking water. 


\section{Preparation of chitosan}

Medium-molecular-weight chitosan in powder form purchased from Sigma-Aldrich (St. Louis, MO, USA) was directly applied to the line of anastomosis. No other processes were applied to the commercial chitosan preparation prior to application.

\section{Assessments}

Rats were sacrificed on their respective postoperative days for assessments. A re-laparotomy was done in the previously used line of incision in sacrificed rats.

\section{Evaluation of adhesions}

At post-mortem examination, adhesions were graded in a scale between 0 and 3 according to the system developed by van Der Ham et al..$^{14}$ : 0, no adhesions; 1 , minimal adhesions, primarily between the omentum and the anastomosis; 2, moderate adhesions, i.e., between the anastomotic site and omentum or between the anastomosis and a loop of the small bowel or abdominal wall; and 3 , severe and extensive adhesions, i.e., between the anastomotic site and several loops of the small bowel and abdominal wall.

\section{Measurement of the colonic bursting pressure}

After the integrity of the anastomosis was ascertained upon exposure of the line of anastomosis and removal of adhesions in the surrounding tissues, two cuts, one $3 \mathrm{~cm}$ proximal and one $3 \mathrm{~cm}$ distal to the anastomosis were made to obtain a $6-\mathrm{cm}$ long colonic segment. The distal end of this segment was ligated using $3 / 0$ silk sutures after an infusion set was inserted into the proximal end. The water pressure was increased gradually and appearance of air bubbles was recorded as the bursting pressure in $\mathrm{mm} \mathrm{Hg}$. Following this measurement, the intestinal segment was cut longitudinally, divided into two segments while preserving the distal sutures, and one-half was placed in $10 \%$ formaline solution. The other half of the sample segment was stored at $-70^{\circ} \mathrm{C}$ for tissue hydroxyproline assay.

\section{Histopathological examination}

Anastomotic segments were stained with hematoxylin and eosin (H\&E) stain and examined with the light microscopy at $20 \mathrm{x}$ and $200 \mathrm{x}$ magnification power by the same pathology specialist blinded to the groups. Inflammatory cell infiltration (leukocyte count), fibroblast activity, neoangiogenesis, and collagen content were determined using Ehrlich and Hunt scale as modified by Philips et al. ${ }^{17}$.

\section{Tissue hydroxyproline assay}

The tissue hydroxyproline concentration, which represents the perianastomotic collagen concentrations, was measured using the spectrophotometric method of Bergman and Loxley ${ }^{15,16}$. The results were expressed in micrograms of hydroxyproline per milligram of tissue $(\mu \mathrm{g} / \mathrm{mg})$.

\section{Statistical analyses}

Results were expressed as mean \pm SEM. Betweengroup differences were evaluated by Kruskal-Wallis test. Multiple comparisons between groups were performed with post-hoc Tukey's HSD test. All analyses were conducted using SPSS 10 software (SPSS, Inc., Chicago, IL, USA). A p value less than 0.05 was considered indication of statistical significance.

\section{Results}

\section{Overall difference between groups}

Tables 1 and 2 show mean values for tested variables in the four experimental groups at three and seven days after the anatomoses. Based on non-parametric variance analysis results (Kruskal-Wallis test), the scores for acute inflammation and neovascularization did not significantly differ between the four groups. On the other hand, other variables revealed significant overall $\mathrm{p}$ values necessitating post hoc analysis.

TABLE 1 - The comparison between chitosan and control group via histopathological analysis in day 3 .

$\begin{array}{cccc}\text { Variable } & \text { Chitosan } & \text { Day } 3 & \text { Control } \\ \text { Acute inflammation* } & 3.75 \pm 0.45 & 3.41 \pm 0.51 & \text { P } \\ \text { Fibroblast activation* } & 2.67 \pm 0.49 & 2.25 \pm 0.45 & 0.096 \\ \text { Collagen* } & 2.25 \pm 0.45 & 2.33 \pm 0.49 & 0.974 \\ \text { Neovascularization* } & 2.92 \pm 0.67 & 2.67 \pm 0.49 & 0.600\end{array}$

Data are presented as mean \pm standard deviation. *Ehrlich and Hunt scale score.

TABLE 2 - The comparison between chitosan and control group via histopathological analysis in day 7

$\begin{array}{cccc}\text { Variable } & \text { Chitosan } & \text { Day 7 } & \\ \text { Control } & \mathrm{P} \\ \text { Acute inflammation* } & 3.75 \pm 0.45 & 3.75 \pm 0.45 & 1.00 \\ \text { Fibroblast activation* } & 3.08 \pm 0.29 & 2.75 \pm 0.45 & 0.241 \\ \text { Collagen* } & 3.42 \pm 0.51 & 2.75 \pm 0.45 & \mathbf{0 . 0 0 7} \\ \text { Neovascularization* } & 3.00 \pm 0 & 2.50 \pm 0.52 & 0.074\end{array}$

Data are presented as mean \pm standard deviation. *Ehrlich and Hunt scale score 


\section{Change in variables over time}

In the chitosan group day 3, a significant increase in collagen score $(2.25 \pm 0.45$ vs. $2.33 \pm 0.49,3.42 \pm 0.51 \mathrm{p}<0.001)$ (Table 1), bursting pressure $(154.17 \pm 44.8$ vs. $70.0 \pm 17.58 \mathrm{mmHg}$, $\mathrm{p}<0.001)$ and adhesion score $(2.0 \pm 0$ vs. $1.42 \pm 0.51, \mathrm{p}=0.007)$ were evident at day 7 when compared to day 3 . In control group (day 3), a significant time dependent increase was observed in only bursting pressure $(192.5 \pm 23.8$ vs. $61.67 \pm 9.37$ vs. $\mathrm{mmHg}$, $\mathrm{p}<0.001)$. Other parameters did not change over time in chitosan subjects and control.

TABLE 3 - Result of bursting pressure, hidroxyproline and adhesion score.
Comparison of chitosan and control groups three and seven days after anastomoses

At three days, chitosan and control groups had similar values for all indices. At seven days, (Table 3), significantly high mean score of collagenization ( $3.42 \pm 0.51$ vs. $2.75 \pm 0.45, \mathrm{p}=0.007$ ) and a significantly high bursting pressure (154.17 \pm 44.8 vs. $192.5 \pm 23.8, \mathrm{p}=0.007$ ) in the chitosan group.

$\begin{array}{cccr}\text { Variable } & \text { Chitosan } & \begin{array}{c}\text { Day } 3 \\ \text { Control }\end{array} & \text { P } \\ \begin{array}{c}\text { Bursting } \\ \text { pressure }(\mathrm{mmHg})\end{array} & 70.0 \pm 17.58 & 61.67 \pm 9.37 & \mathbf{0 . 0 4 7} \\ \begin{array}{c}\text { Adhesion } \\ \text { score }\end{array} & 1.42 \pm 0.51 & 1.50 \pm 0.52 & 0.961 \\ \begin{array}{c}\text { OH-prolin } \\ (\mu \mathrm{g} / \mathrm{mg} \text { tissue })\end{array} & 570.6 \pm 68.09 & 372.3 \pm 67.6 & \mathbf{0 . 0 0} \\ \quad \text { Data are presented as mean } \pm \text { standard deviation. * Ehrlich }\end{array}$

and Hunt scale score

\section{Discussion}

Despite advances in surgery, anastomotic leaks of the gastrointestinal system continue to represent a common problem with associated morbidity and mortality. Until now, although numerous clinical and experimental studies have examined local and systemic factors affecting the wound healing in anastomoses, there are no widely available local or systemic agents to reduce leaks in high-risk patients and to facilitate the wound healing, which is a highly complex biological process that involves cell division, chemotaxis, neovascularisation, extracellular matrix protein synthesis, and scar formation ${ }^{18}$.

Healing in intestinal anastomoses conform to the general principles of wound healing, such that edema and inflammation prevail in the initial four days. Inflammatory stage is very crucial for the scavenger activity of inflammatory cells in the wound site $^{18}$ and the presence of inflammatory cells is a sign of tissue repair $^{19}$. As in all anastomoses, tissue circulation and oxygenation play a major role in the healing of colonic anastomoses ${ }^{19,20}$. Chitosan has been found to have a myriad of biological properties such as antimicrobial effects, acceleration of wound healing, activation of macrophages, increasing fibroblast migration and proliferation, and stimulation of angiogenesis, collagen production, and interleukin- 8 secretion by the fibroblasts ${ }^{21-25}$. For instance, in support of these abovementioned effects, Ishihara et $a l{ }^{26}$ found a significant increase in angiogenesis at the wound site with a mixture of chitosan and FGF-2 compared to controls. It is no surprise that neovascularization represents an important factor to combat infections, in the light of the fact that oxygen, leucocytes, and immunoglobulins are carried to the wound site by the very same vascular structures ${ }^{27}$. In our study however, a significant difference between chitosan and control group could not be detected with regard to neovascularization, probably due to the small duration of follow-up. Moreover, a number of previous studies have shown that different molecular weights of chitosan have a range of antiinflammatory actions, including inhibition of the production of TNF- $\alpha$, IL-6, prostaglandin E2 (PGE2), cyclooxygenase-2 (COX-2), VCAM-1 and ICAM-1 in vitro ${ }^{28,29}$. Qiao Y. et al. ${ }^{8}$ reported decreases in oxidative tissue injury, septic injury, organ injury, and cytokine levels ${ }^{8}$. These somehow conflicting findings may be explained on the basis of differential effects of chitosan with varying doses. Likewise, rats sacrificed 
on day 3 showed no difference in acute inflammation, while significantly more marked acute inflammation was found in rats in Chitosan 2 group compared to those in group 2 that were sacrificed on day 7 . This suggests that chitosan may boost the inflammatory response in a short period of time such as seven days.

Anastomotic failure is associated with excessive collagen breakdown or inadequate formation of new collagen. The two main factors leading to this result include the higher level of collagenase activity in the wounded rectum and colon wall compared to the remaining parts of the gut and abscess formation due to faecal contamination at the site of or near the anastomosis. Kiyama et $a l .^{30}$ suggested that inhibition of collagenase activity results in decreased collagenolysis, indirectly causing enhanced storage of anastomotic collagen with the resultant healing at the site of colon anastomosis. The probable origin of collagenase activity, which plays an important role for the integrity of the anastomosis during the initial days, is the tissues near and at the line of anastomosis, although the synthesis and source of collagenase enzyme are yet to be defined more precisely. Elucidation of this latter point may provide deeper insights into the wound healing process ${ }^{31-33}$. An in-vitro study by Nastasescu et al. ${ }^{34}$ showed decreased collagen breakdown after addition of a collagen-chitosan mixture into a body fluid containing collagenase. In the present study, we believe that the emergence of a significant difference between the two groups at day 7 and day 3 .

Colonic bursting pressure is a sign of the mechanical endurance of the anastomosis ${ }^{35}$. In a study by Xiao H. et al. ${ }^{36}$ the impact of a carboxymethylchitosan-carboxymethylcellulose (CMCH-CMC) film applied to the surface of anastomosis on wound healing was explored in rats. They found an increased rate of adhesions nearby the anastomosis without an observable effect on anastomotic healing. Nursal et al. ${ }^{37}$ suggested that agents that cause excessive increase or decrease in inflammation may cause undesired effects on wound healing ${ }^{38,39}$. Our study shows that the bursting pressure of the chitosan application group on day 3 and day 7 were significantly higher when compared to the control groups. However no differences with regard to intra-abdominal adhesions between chitosan and control groups. However, significantly higher rate of adhesions were observed in chitosan 2 group compared to chitosan 1, which was probably due to slow absorption of chitosan in the abdominal cavity leading to fibrous capsule formation and enhanced foreign body reaction.

Although our results have not lend support to clinical use of chitosan to improve the safety of anastomoses, further studies may help to better define the role of chitosan in the healing of colonic anastomoses since the significant increase in collagenization among chitosan groups may deserve investigation.

\section{Conclusion}

Our study emphasizes the positive effect of chitosan in the process of collagenation in colonic anastomosis healing.

\section{References}

1. Choy PY, Bissett IP, Docherty JG, Parry BR, Merrie A, Fitzgerald A. Stapled versus handsewn methods for ileocolic anastomoses. Cochrane Database Syst Rev. 2011;(9):CD004320.

2. Harris LJ, Phillips BR, Maxwell PJ, Isenberg GA, Goldstein $\mathrm{SD}$. Outcomes of low anterior resection anastomotic leak after preoperative chemoradiation therapy for rectal cancer. Am Surg. 2010;76(7):747-51.

3. Buchs NC, Gervaz P, Secic M, Bucher P, Mugnier-Konrad B, Morel P. Incidence, consequences, and risk factors for anastomotic dehiscence after colorectal surgery: a prospective monocentric study. Int J Colorectal Dis. 2008;23(3):265-70.

4. Luján JJ, Németh ZH, Barratt-Stopper PA, Bustami R, Koshenkov VP, Rolandelli RH. Factors influencing the outcome of intestinal anastomosis. Am Surg. 2011;77(9):1169-75.

5. Volk A, Kersting S, Held HC, Saeger HD. Risk factors for morbidity and mortality after single-layer continuous suture for ileocolonic anastomosis. Int J Colorectal Dis. 2011;26(3):321-7.

6. Rinaudo M. Chitin and chitosan: properties and applications. Prog Polym Sci. 2006;31:603-32.

7. Prabaharan M. Review paper: chitosan derivatives as promising materials for controlled drug delivery. J Biomater Appl. 2008;23(1):5-36

8. Qiao Y, Bai XF, Du YG. Chitosan oligosaccharides protect mice from LPS challenge by attenuation of inflammation and oxidative stress. Int Immunopharmacol. 2011;11(1):121-7.

9. Fernandes JC, Spindola H, de Sousa V,Santos-Silva, PintadoME, Malcata FX, Carvalho JE. Anti-inflammatory activity of chitooligosaccharides in vivo. Mar Drugs. 2010;8(6):1763-8.

10. Alemdaroğlu C, Değim Z, Celebi N, Zor F, Oztürk S, Erdoğan D. An investigation on burn wound healing in rats with chitosan gel formulation containing epidermal growth factor. Burns. 2006;32(3):319-27.

11. Ishihara M, Ono K, Sato M, Nakanishi K, Saito Y, Yura H, Matsui T, Hattori H, Fujita M, Kikuchi M, Kurita A. Acceleration of wound contraction and healing with a photocrosslinkable chitosan hydrogel. Wound Repair Regen. 2001;9(6):513-21.

12. Değim Z, Celebi N, Sayan H, Babül A, Erdoğan D, Take G. An investigation on skin wound healing in mice with a taurine-chitosan gel formulation. Amino Acids. 2002;22(2):187-98.

13. Uludag M, Ozdilli K, Citgez B, Yetkin G,Ipcioglu OM, Ozcan O, Polat N, Kartal A,Torun P, Isgor A. Covering the colon anastomoses with amniotic membrane prevents the negative effects of early intraperitoneal 5-FU administration on anastomotic healing. Int J Colorectal Dis. 2010;25(2):223-32.

14. van der Ham AC, Kort WJ, Weijma IM, van den Ingh HF, Jeekel H. Effect of antibiotics in fibrin sealant on healing colonic anastomoses in the rat. Br J Surg. 1992;79(6):525-8.

15. Bergman I, Loxley R. Two improved and simplified methods for the spectrophotometric determination of hydroxyproline. Ann Chem. $1963 ; 35: 1961-5$ 
16. Lee HS, Huang GT, Chen CH, Chiou LL, Lee CC, Yang PM, Chen DS, Sheu JC. Less reversal of liver fibrosis after prolonged carbon tetrachloride injection. Hepatogastroenterology. 2001;48(41):13125.

17. Phillips JD, Kim CS, Fonkalsrud EW, Zeng H, Dindar H. Effects of chronic corticosteroids and vitamin A on the healing of intestinal anastomoses. Am J Surg. 1992;163(1):71-7.

18. Brown GL, Nanney LB, Griffen J, Cramer AB, Yancey JM, Curtsinger LJ 3rd, Holtzin L, Schultz GS, Jurkiewicz MJ, Lynch JB Enhancement of wound healing by topical treatment with epidermal growth factor. N Engl J Med. 1989;321(2):76-9.

19. Hillan K, Nordlinger B, Ballet F, Puts JP, Infante R. The healing of colonic anastomoses after early intraperitoneal chemotherapy: an experimental study in rats. J Surg Res. 1988;44(2):166-71.

20. Irkorucu O, Ucan BH, Cakmak GK, Tascilar O, Emre AU, Ofluoglu E, Bahadir B, Karakaya K, Demirtas C, Pasaoglu H, Ankarali H, Comert M. Effect of 2-octyl-cyanoacrylate on ischemic anastomosis of the left colon. J Invest Surg. 2009;22(3):188-94.

21. Ishihara M, Nakanishi K, Ono K, Sato M, Kikuchi M, Saito Y, Yura H, Matsui T, Hattori H, Uenoyama M, Kurita A. Photocrosslinkable chitosan as a dressing for wound occlusion and accelerator in healing process. Biomaterials. 2002;23(3):833-40.

22. Rao SB, Sharma CP. Use of chitosan as a biomaterial: studies on its safety and hemostatic potential. J Biomed Mater Res. 1997;34(1):218 .

23. Mori T, Okumura M, Matsuura M, Ueno K, Tokura S, Okamoto Y, Minami S, Fujinaga T. Effects of chitin and its derivatives on the proliferation and cytokine production of fibroblasts in vitro. Biomaterials. 1997;18(13):947-51.

24. Ishihara M, Obara K, Ishizuka T, Fujita M, Sato M, Masuoka K, Saito Y, Yura H, Matsui T, Hattori H, Kikuchi M, Kurita A. Controlled release of fibroblast growth factors and heparin from photocrosslinked chitosan hydrogels and subsequent effect on in vivo vascularization. J Biomed Mater Res A. 2003;64(3):551-9.

25. Ueno H, Yamada H, Tanaka I,Kaba N, Matsuura M, Okumura M, Kadosawa t, Fujinaga T. Accelerating effects of chitosan for healing at early phase of experimental open wound in dogs. Biomaterials. 1999;20(15):1407-14.

26. Ishihara M, Obara K, Nakamura S, Fujita M, Masuoka K, Kanatani Y, Takase B, Hattori H, Morimoto Y, Ishihara M, Maehara T, Kikuchi M. Chitosan hydrogel as a drug delivery carrier to control angiogenesis. J Artif Organs. 2006;9(1):8-16.

27. Ueno H, Nakamura F, Murakami M, Okumura M, Kadosawa T, Fujinag T. Evaluation effects of chitosan for the extracellular matrix production by fibroblasts and the growth factors production by macrophages. Biomaterials. 2001;22(15):2125-30.

28. Chou TC, Fu E, Shen EC. Chitosan inhibits prostaglandin E2 formation and cyclooxygenase-2 induction in lipopolysaccharidetreated RAW 264.7 macrophages. Biochem Biophys Res Commun. 2003;308(2):403-7.

29. Kim MS, Sung MJ, Seo SB, Yoo SJ, Lim WK, Kim HM. Watersoluble chitosan inhibits the production of pro-inflammatory cytokine in human astrocytoma cells activated by amyloid beta peptide and interleukin-1beta. Neurosci Lett. 2002;321(1-2):105-9.

30. Kiyama T, Onda M, Tokunaga A, Efron DT, Barbul A. Effect of matrix metalloproteinase inhibition on colonic anastomotic healing in rats. J Gastrointest Surg. 2001;5(3):303-11.

31. Thornton FJ, Barbul A. Healing in the gastrointestinal tract. Surg Clin North Am. 1997;77(3):549-73.

32. Agren MS, Andersen TL, Mirastschijski U, Syk I, Schiødt CB, Surve V, Lindebjerg J, Delaissé JM. Action of matrix metalloproteinases at restricted sites in colon anastomosis repair: an immunohistochemical and biochemical study. Surgery. 2006;140(1):72-82.
33. Cohen CI, Diegelmann RF, Yager DR. Wound care and wound healing. In: Schwartz SI, Shires GT, Spencer FC. Principles of surgery. 7ed. New York: McGraw-Hill; 1999. p.263-95.

34. Nastasescu OS, Popa IM, Verestiuc L, Butnaru M, Baran D. Scaffolds based on collagen and chitosan for post-burn tissue engineering. Rev Med Chir Soc Med Nat Iasi. 2008;112(2):547-53.

35. Kanellos I, Mantzoros I, Demetriades H, Kalfadis S, Kelpis T, Sakkas L, Betsis D. Healing of colon anastomoses covered with fibrin glue after immediate postoperative intraperitoneal administration of 5-fluorouracil. Dis Colon Rectum. 2004;47(4):510-5.

36. Xiao H, Hou C, Xue F. Effect of carboxymethylchitosancarboxymethylcellulose film on colonic anastomosis healing. Zhongguo Xiu Fu Chong Jian Wai Ke Za Zhi. 2009;23(4):451-5.

37. Nursal TZ, Anarat R, Bircan S, Yildirim S, Tarim A, Haberal M. The effect of tissue adhesive, octyl-cyanoacrylate, on the healing of experimental high-risk and normal colonic anastomoses. Am J Surg. 2004;187(1):28-32.

38. Zhou XL, Chen SW, Liao GD, Shen ZJ, Zhang ZL, Sun L, Yu YJ, $\mathrm{Hu}$ QL, Jin XD. Preventive effect of gelatinizedly-modified chitosan film on peritoneal adhesion of different types. World J Gastroenterol. 2007;13(8):1262-7.

39. Zhang ZL, Xu SW, Zhou XL. Preventive effects of chitosan on peritoneal adhesion in rats. World J Gastroenterol. 2006;12(28):45727.

\section{Correspondence:}

Oguzhan Karatepe

Bezmialem Vakif Universty

Department of Hepatobiliary and Pancreatic Surgery

34715, 00905335408070

drkaratepe@yahoo.com

Received: May 11, 2012

Review: July 12, 2012

Accepted: August 14, 2012

Conflict of interest: none

Financial source: none

${ }^{1}$ Research performed at Experimental Medical Research Center, Istanbul University, Turkey. 